\title{
MEMORIES OF THE MAYA: NATIONAL HISTORIES, CULTURAL IDENTITIES, AND ACADEMIC ORTHODOXY
}

\author{
KATHRYN M. HUDSON \\ UNIVERSITY AT BUFFALO \\ JOHN S. HENDERSON \\ CORNELL UNIVERSITY
}

\begin{abstract}
John Lloyd Stephens and Frederick Catherwood's travel accounts celebrating ancient Maya sculpture and architecture set the stage for the emphasis of the Maya as the pinnacle of cultural development in Mexico and Central America and for the appropriation of Maya prehistory as the foundation of modern national histories and identities. In the twentieth century, these discourses intensified into two interconnected hegemonic narratives - one in syntheses of precolumbian history by North American archaeologists and the other in national histories produced in Central America - that privileged the Maya as a source of history, legitimacy, and identity. This paper explores these narratives as they occur in Honduras through three distinct but interrelated lenses: academic discourse on Honduran archaeology; the conceptualization and development of a Honduran national identity; and the engagement of descendant groups with this constructed heritage. Considered together, these perspectives illuminate the complex cultural and political foundation(s) of memory.

Keywords: United States; Honduras; Maya; archaeological sites; indigenous people; identity discourses; memory
\end{abstract}

DOI: $10.14712 / 23363231.2021 .8$

Kathryn Hudson, PhD is Research Assistant Professor, Department of Anthropology, University at Buffalo. John S. Henderson, PhD is Professor of Archaeology, Department of Anthropology, Cornell University. Address correspondence to John S. Henderson, Department of Anthropology, 225 McGraw Hall, Cornell University, Ithaca, NY 14853, USA. E-mail: jsh6@cornell.edu. 


\section{Introduction}

The population of the territory corresponding to what is now the República de Honduras, like that of the rest of Central America, has always been linguistically, culturally, and ethnically diverse. In precolumbian times the largest political entities, city-states, were limited in territorial scale and were relatively homogeneous linguistically and culturally. The sixteenth-century Spanish invasions of what would become Mexico and Central America led to the formation of colonial administrative structures that were far more territorially extensive than any precolumbian polity. The arrival of people with various Iberian, other European, and African identities substantially complicated the landscape of cultural diversity, even as forced homogenization and various forms of genocide began to erase the indigenous cultural spectrum. The dominance of a Spanish identity in the colonial context made any other kind of national identity a non-issue.

Following the wars of independence in the first quarter of the nineteenth century, national identity became a salient issue for newly independent countries throughout Spanish America, especially those, like Honduras, that had emerged from the Colonial period without distinctive identities. History is always the main well-spring of elements that make up identities and, in the case of the former Spanish colonies, the precolumbian past was far more likely than colonial history to provide distinctive features that would set them apart from the rest of Spanish America. This was especially obvious and attractive for countries whose precolumbian history included ancient civilizations that had left monumental architecture and sculpture and other impressive remains. Honduras and Guatemala drew heavily on the ancient Maya for new definitions of national identity; comparable processes were at work in Mexico with the Aztec past, in Peru with Inka monuments, and in other corners of Spanish America with less spectacular remains. In the United States, the relationship of the precolumbian past to contemporary identities was complicated by the widespread perception that archaeological remains were at once insufficiently impressive to provide historical roots for the new nation that could complete with the European heritage based on antiquities of the Mediterranean and Near East, yet too large and elaborate to be within the imagined capabilities of indigenous North American peoples. During the nineteenth century and the first decade of the twentieth, the possibility of appropriating the precolumbian monuments of Mexico and Central America seemed to provide the answer.

Here we analyze the history of how the precolumbian past in Honduras has been mobilized by state actors and public intellectuals to provide the foundations 
of a national identity. We follow these developments mainly as they are reflected in accounts and syntheses of archaeological research written by archaeologists, historians, and others for both academic and popular audiences; beginning with the last quarter of the twentieth century, our personal observations supplement published documents. This history is largely the story of archaeological documentation of Copán, a first millennium CE Maya city-state in far western Honduras. Early celebration of Copán's spectacular architecture and sculpture in the popular travel accounts of Stephens and Catherwood notwithstanding, ${ }^{1}$ Lempira - a hero of local resistance to the Spanish invasion known only from a few casual mentions in documents - was an early focus of an emerging national identity discourse. He was eventually subsumed and marginalized by arowing emphasis on the Maya and their impressive material remains, though his significance was never entirely erased.

Our analysis highlights a particularly interesting dimension of the success of the Honduran national identity and history: its Maya-ness. The account of Honduras as Maya was founded on archaeological work revealing and celebrating the grandeur of ancient Maya city-states in general and of Copan in particular, but it departs from archaeological orthodoxy in significant ways. The story of Honduran Maya history represents precolumbian remains throughout the republic as Maya, whereas archaeological orthodoxy insists that the ancient Maya inhabited only the northwestern fringe of the country around Copán. The information produced by archaeologists was essential to the project, but archaeologists' understanding of it was not.

The parallel history of discourse about the ancient Maya in North America - also drawn from technical and synthetic popular writing on the Maya and from personal observation - provides an illuminating complementary perspective. Early inclinations in the United States to coopt the impressive monumental remains of Mexico and Central America, particularly Copán, foundered on the impracticality of actually taking possession of the physical monuments. Control of impressive monumental remains themselves is absolutely critical to national heritage/identity projects. The triumph of the Maya and their majestic architecture and sculpture in the development of Honduran identity provides an instructive perspective on national identity formation and the power of memory politics.

1 John L. Stephens, Incidents of Travel in Central America, Chiapas, and Yucatan, 2 vols. (New York: Harper and Brothers, 1841). 


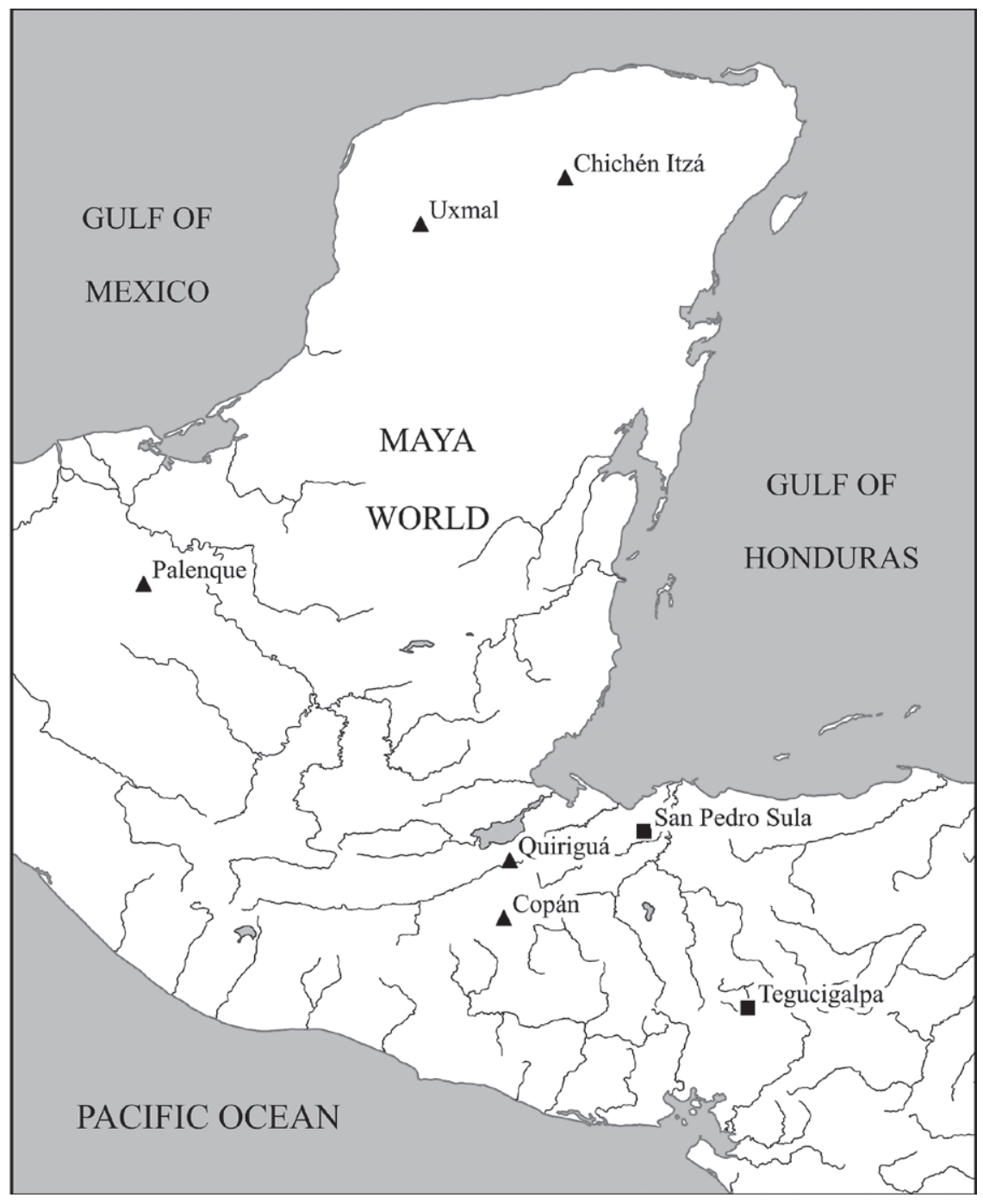

Figure 1. Honduras and the Maya world. Map by John S. Henderson. 


\section{Copán and the Maya}

The archaeological remains of America's ancient civilizations were never "lost" from the perspective of local residents. In Yucatan, where Maya monumental buildings and sculptures were apparent to residents of the main seats of government, and in the highlands of Guatemala, where the Spanish invasion coincided with the heyday of the K'iche' and Kaqchikel Maya kingdoms, the ruins of whose capital cities lay close to the colonial capital, the Maya past was always obvious and accessible. In Honduras, recognition of the potential contribution of the precolumbian past to a national identity had to await the "rediscovery" of the Maya remains of Copán during the nineteenth century. At the same time, the remains of Maya civilization emerged as the most spectacular facet of the archaeological record throughout Central America. North American archaeologists and institutions took the lead in documenting and analyzing the material remains of ancient Maya city-states, providing the basis for academic and public recognition of the Maya as the New World equivalent of the ancient peoples of the Mediterranean and Near East who were perceived to be at the roots of the Western tradition of civilized life. This was especially true in Honduras, where until the mid-twentieth century - the focus was almost exclusively on North American projects at Copán that laid the groundwork for the development of a precolumbian Maya foundation for Honduran national identity.

In 1841, Incidents of Travel in Central America, Chiapas, and Yucatan, the first of two wildly successful accounts of Maya ruins by John Lloyd Stephens, exquisitely illustrated by Frederick Catherwood, brought Copán and other major Maya cities that had flourished in the fifth through eighth centuries to the attention of an international readership. ${ }^{2}$ At Copán, in far western Honduras (Fig. 1), it was the deeply carved reliefs that captured the attention of Stephens, Catherwood, and their readers (Fig. 2). In Yucatan, it was the elaborately decorated standing architecture of cities like Uxmal.

Stephens's agendas were put on display from the outset. At Copán, the first site they visited on their initial visit to Central America, Stephens was so enchanted with Copán's sculpture that he managed to persuade the mayor of the local village to sell the ruins to him for the sum of fifty dollars. He dreamt of shipping the monuments to New York where they could be displayed for the edification of an admission-paying public. The plan never materialized; nor did his attempts to buy other Maya sites. Stephens and Catherwood did, however,

2 Stephens, Incidents of Travel in Central America, Chiapas, and Yucatan. 


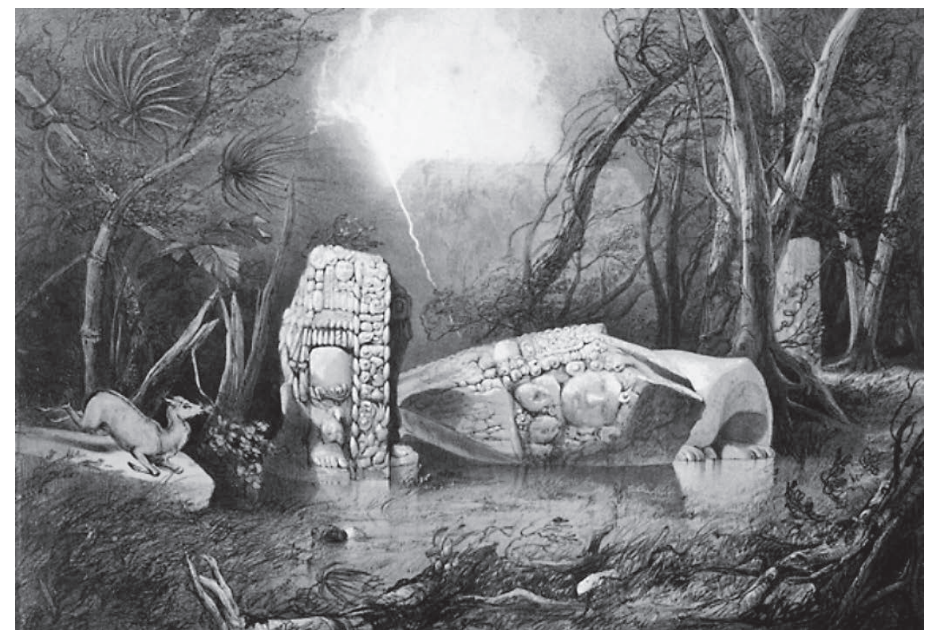

Figure 2. Copán, Stela C. Watercolor by Frederick Catherwood (Views of Ancient Monuments in Central America, Chiapas, and Yucatán, Plate IV, https://www.jstor.org/stable/community.13557132.

manage to steal a variety of artifacts, including a few carved monuments. Most were destroyed when Catherwood's exhibition hall burned; a few found their way to museums. ${ }^{3}$

Especially in the United States, public interest in the art and architecture of ancient Maya cities - above all the great temples and palaces and the relief carving depicting what we now know to be Maya kings - had been piqued and the resulting identification with elegant monumentality would never fade. The growing influence of the newly established Church of Jesus Christ of Latter-day Saints, which proclaimed that all of the indigenous peoples of the Americas were descended from migrants from the Holy Land, helped to sustain public interest in the precolumbian monuments of Mexico and Central America. In the later nineteenth century, especially in the 1870s and 1880s, interpretations of Désiré Charnay and Alice and Augustus Le Plongeon kept precolumbian civilizations, especially the ancient Maya in the public eye. Their ideas departed substantially

3 R. Tripp Evans, Romancing the Maya: Mexican Antiquity in the American Imagination 1820-1915 (Austin: University of Texas Press, 2004), 54-55; Victor W. von Hagen, Frederick Catherwood, Archt. (New York: Oxford University Press, 1950). 


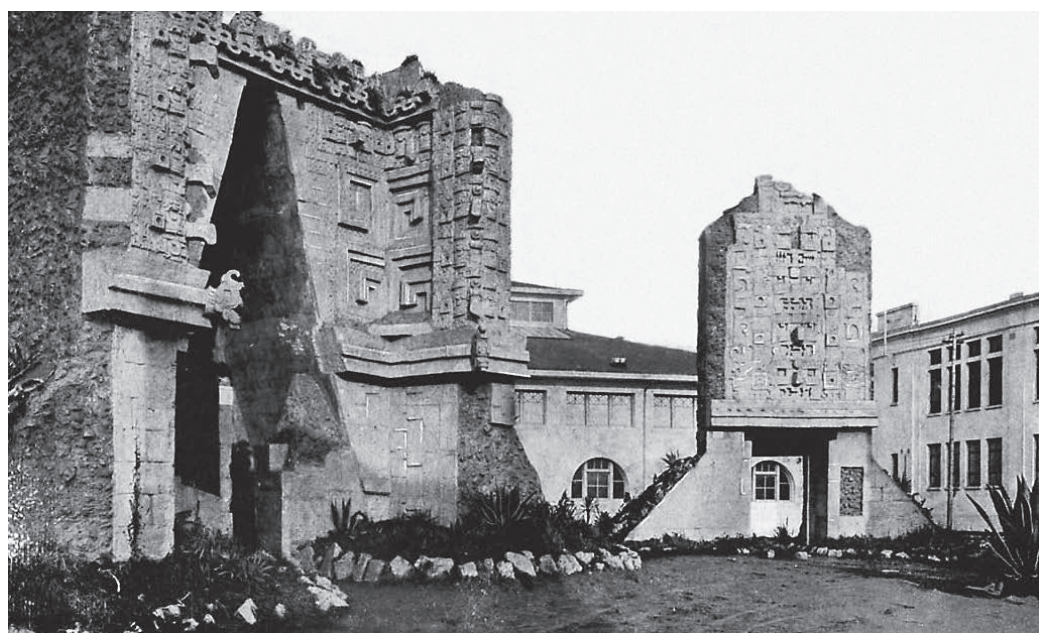

Figure 3. World Columbian Exposition, replicas of buildings at Uxmal. Photograph by William Rand and Andrew McNally (The Columbian Exposition Album, Chicago: Rand, McNally \& Co., 1893, unpaginated).

from conventional scholarship, but their documentation of precolumbian sculpture and architecture, especially Maya monuments, through photography and mold-making began to lay the foundations for an academic approach to precolumbian history. ${ }^{4}$ The idea of transporting Maya monuments to the United States also persisted. In 1882, the newly founded Smithsonian Institution dispatched John F. Bransford to Honduras to assess the feasibility of crating up buildings and sculptures, transporting them to the coast, and shipping them to the United States. ${ }^{5}$ Reality intervened once again. A decade later, the World's Columbian Exposition in Chicago, celebrating the 400th anniversary of the first voyage of

4 Evans, Romancing the Maya, 103-160; Désiré Charnay, Cités et ruines américaines: Mitla, Palenqué, Izamal, Chichen-Itza, Uxmal (Paris: A. Morel et Cie., 1863); Désiré Charnay, The Ancient Cities of the New World: Being Travels and Explorations in Mexico and Central America from 1857-1882 (London: Chapman \& Hall, 1887); Augustus Le Plongeon, Vestiges of the Mayas (New York: John Polhemus, 1881); Lawrence G. Desmond and Phyllis Messenger, A Dream of Maya: Augustus and Alice Le Plongeon in Nineteenth Century Yucatan (Albuquerque: University of New Mexico Press, 1988).

5 John F. Bransford, Report on explorations in Central America, in 1881. Miscellaneous Papers Relating to Anthropology from the Smithsonian Report for 1882 (Washington, D.C.: Government Printing Office, 1883), 129-151. 
Columbus, approached the enterprise of appropriating the impressive Maya past in a different way. Full-scale replicas of Maya buildings were built in the midway space (Fig. 3) alongside exhibits populated with large-scale photographs, portable artifacts, and indigenous people brought from Mexico. ${ }^{6}$

Meanwhile, Alfred Percival Maudslay laid the foundations for the first major academic investigation of an ancient Maya city: the Harvard investigations at Copán. Maudslay spent the spring of 1885 at Copán mapping the ruins, documenting sculpture and hieroglyphic inscriptions, and excavating several structures. His work helped maintain interest in Copán and the Maya on the part of Honduran politicians, government officials, and intellectuals and set the stage for the multi-year project undertaken by the Peabody Museum at Harvard University in the 1890s. ${ }^{7}$ Those investigations made Copán the focus of academic interest in the Maya, especially in the United States, and cemented its position as the centerpiece of precolumbian Honduran history. The Peabody Museum archaeologists, like their predecessors at Copán and their contemporaries working elsewhere in the Maya world, were operating in an antiquarian mode: they were primarily interested in large buildings and the sculpture associated with them. They repaired and re-set some of the stelae (Fig. 4) - freestanding monuments with what would eventually be identified as royal portraits and hieroglyphic texts celebrating the lives of the city's kings - that were set in the main plaza and they consolidated and rebuilt palaces and temples in the central civic precinct.

The Copán project was the first extensive program of mapping and excavation at a Maya city. Along with contemporaneous investigations of ancient cities elsewhere in the Maya lowlands by explorers like Maudslay and Teobert Maler, interpretations of iconography and hieroglyphic texts by Ernst Förstemann and Eduard Seler, and the publicity generated by the World's Columbian Exposition in Chicago, it played a major role in solidifying the impressions fostered by Stephens and Catherwood. Ancient Maya civilization was established as an impressive cultural achievement on a par with its Old World counterparts. And the Peabody Museum was established as the preeminent institution engaged in revealing the grandeur of ancient Maya civilization and elucidating precolumbian history

6 Evans, Romancing the Maya, 153-162.

7 George Byron Gordon, Prehistoric Ruins of Copán, Honduras: A Preliminary Report of the Explorations by the Museum 1891- 1895, Memoirs of the Peabody Museum of American Archaeology and Ethnology 1, no. 1 (Cambridge: Harvard University, 1896); George Byron Gordon, The Hieroglyphic Stairway, Ruins of Copán, Memoirs of the Peabody Museum of American Archaeology and Ethnology 1, no. 6 (Cambridge: Harvard University, 1902). 


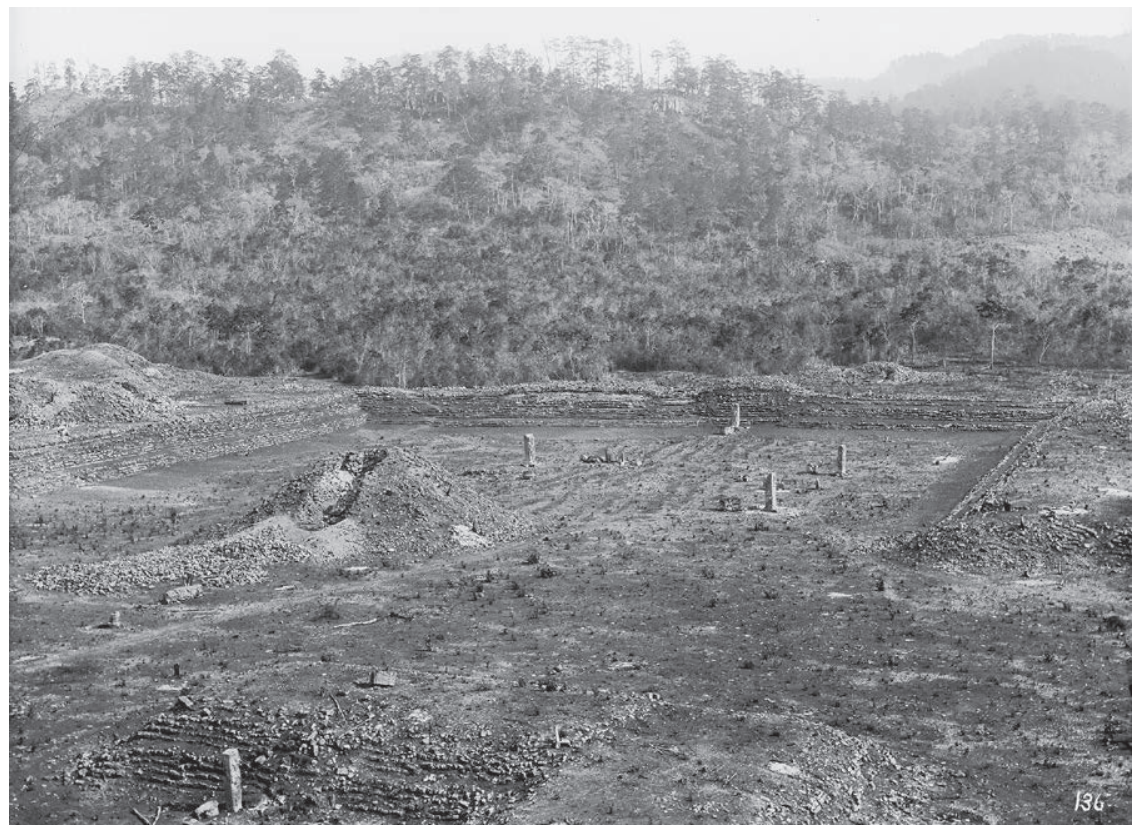

Figure 4. Copán, Great Plaza and stelae during Peabody Museum project circa 1895. Photograph courtesy of the Peabody Museum of Archaeology and Ethnology, Harvard University, 2004.24.136.1.

in the Americas, and as the repository for impressive precolumbian artistic achievements and for important research collections.

The archeological landscape created by the work at Copán fostered the engagement of Hondurans - at least those living in the surrounding region and those who were sufficiently prosperous and intrepid to travel there from the major cities - with what would come to be the key feature of the national past. The Peabody Museum archaeologists understood it as a re-creation of the ancient city - partial, but faithful to the intentions of its ancient Maya designers - and its focus was resolutely on grand buildings and sculpture. Copán's archaeological landscape, expanded and elaborated again and again in subsequent decades, would become the focus of a national identity project built around association with the ancient Maya and it would shape that identity in unexpected ways. The materialization of a Maya heritage in Copán's archaeological landscape had at its core the apparatus of ancient city-states and the monuments that legitimized 
them and kept the elite class that controlled them in power. The precolumbian monuments being mobilized to create a modern national identity had once been the reflection of an ancient identity: that of the rulers of Maya city-states. The parallel between the ancient and contemporary functions of the monuments was inescapable. Whatever the hope for inclusiveness that would embrace all Hondurans in a distinctive new kind of citizenship and whatever solidarity across class lines the archaeology of Copán might have fostered, when the new national identity crystallized it served to naturalize a hierarchical socio-economic order and the concentration of political power in the hands of its elite. In the last decade of the nineteenth century, the contribution of the Peabody Museum project to a Maya-focused Honduran identity was a potential yet to be realized.

One great unknown was the degree to which the archaeology of the rest of the territory of the new republic matched what the Peabody Museum investigations had revealed at Copán, which lies only a few kilometers from the western frontier with Guatemala. The beginnings of an answer were provided by explorations the Peabody expedition undertook in the lower Ulúa valley some 200 kilometers to the east during a period in which the work at Copán had to be suspended because of strained relations with government officials. ${ }^{8}$ The great temples and palaces, monumental sculpture, and hieroglyphic texts that were so fascinating at Copán - and so revered by the notions of historical significance that motivated American archaeologists - were not present in the lower Ulúa valley. Gordon, who directed the investigations there, concluded that the region must have been occupied by non-Maya people whose societies were less complex and therefore less interesting than those of their Maya neighbors to the west. It is a perspective that proved to be very long-lasting among foreign archaeologists working in Honduras, but one that had noticeably less impact on Honduran, public intellectuals, and politicians.

\section{Lempira and Mestizaje}

Another contender for the focus of an emergent national identity during the last decades of the nineteenth century was Lempira (Fig. 5), a cacique from the

8 George Byron Gordon, Researches in the Uloa Valley, Honduras, Memoirs of the Peabody Museum of American Archaeology and Ethnology 1, no. 4 (Cambridge: Harvard University, 1898); Kathryn M. Hudson, "George Byron Gordon and the Birth of a Colonialist Archaeology on the Southeastern Mesoamerican Frontier," Histories of Anthropology Annual 7 (2011): 246-264, doi: 10.1353/haa.2011.0010. 


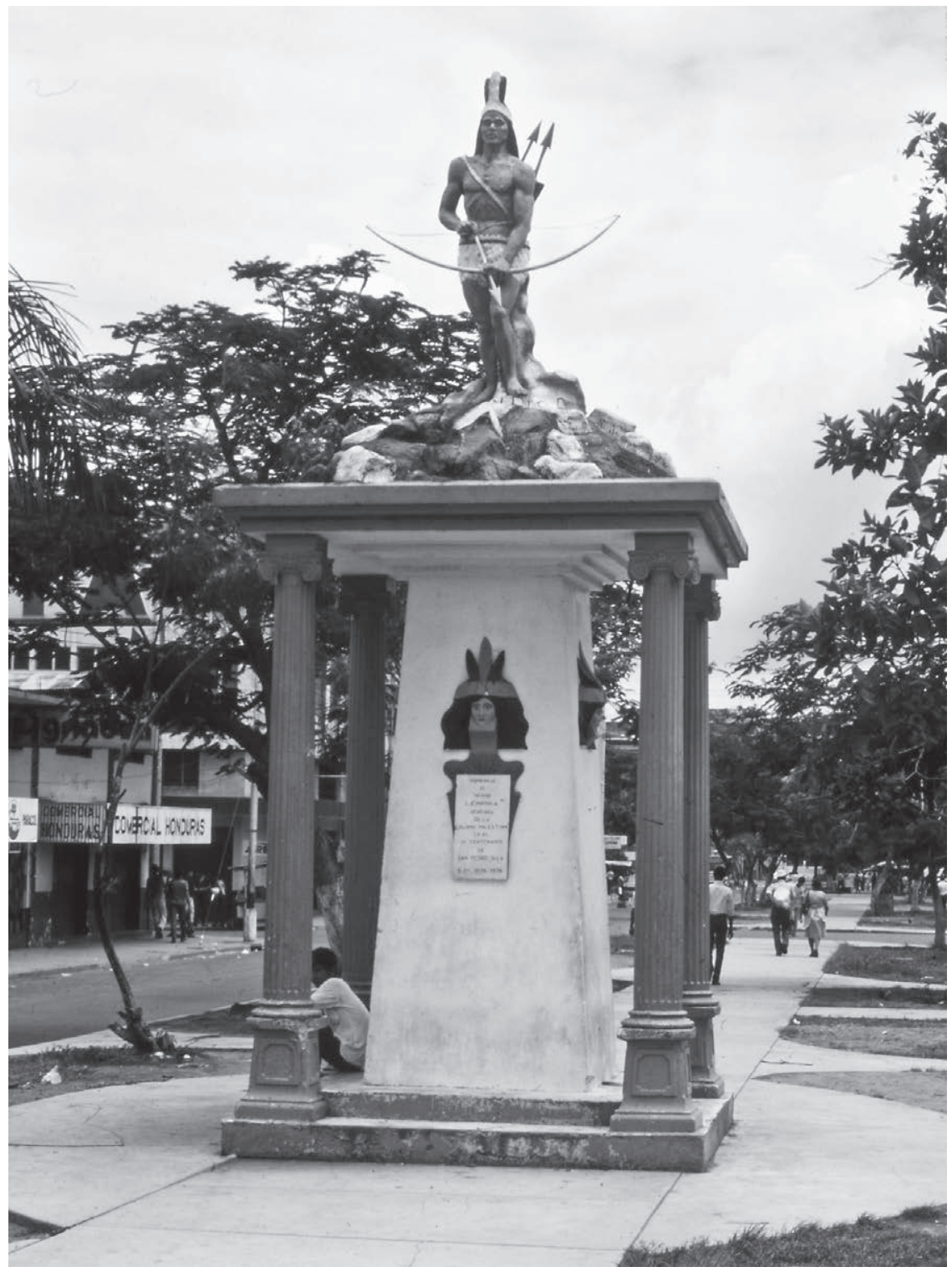

Figure 5. San Pedro Sula, statue of Lempira. Photograph by John S. Henderson. 
western part of the country, south and east of Copán. ${ }^{9}$ At the time of the Spanish invasion, this region was occupied by the Lenca, speakers of a now extinct non-Mayan language, and by other non-Maya groups. Although early Colonial period documents mention a figure that more or less corresponds to the Lempira of Honduran folklore, the Lempira of the public imagination - who heroically led the doomed resistance against Spanish invaders - was a creation of the late nineteenth and early twentieth centuries. Like the Copán Maya, Lempira could embody a precolumbian indigenous heritage - but in a different way. He was an individual drawn from historical documents, whereas the Maya were a collectivity materialized (for Hondurans) in buildings and sculpture at Copán. The invention of Lempira represents the beginning of a conception of the national identity as an aspect of mestizaje, a many-faceted notion embracing the blending of peoples that produced new hybrid ethnicities and cultures. Lempira could be imagined as an inclusive component of Honduran identity that was capable of reaching across socioeconomic lines, but - like the Copán Maya constructed by archaeology - mestizaje contained within it the seeds of exclusivity. Mestizos do not identify with the indigenous tradition, but they also do not qualify as members of dominant elites who are even more European and less indigenous. ${ }^{10}$ They are, in many ways, a category apart.

Elaboration of the Lempira legend continued into the early decades of the twentieth century. His heroic resistance and sacrifice were celebrated in the lyrics of the himno nacional, formally adopted in 1915. The naming of the new national currency after Lempira in the early 1930s solidified his status as a national hero; his portrait on small-denomination coins and the one Lempira note (Fig. 6) ensured that the widest possible national audience would be reminded of his significance on a daily basis. As the twentieth century wore on, images of Copán's Maya architecture and sculpture increasingly framed Lempira's image on Honduran banknotes. This reflects yet another dimension of mestizaje: an attempt to fuse Lempira and the ancient Maya. Lempira embodies the transformation of the indigenous tradition into a Mayanized form that could be harnessed for the benefit of the elite, who identified themselves as European and white.

It is interesting that the official adoption of Lempira by the Honduran state coincided with a period of intense xenophobia in the country. Dario Euraque

\footnotetext{
${ }^{9}$ Darío A. Euraque, “Antropólogos, arqueólogos, imperialismo y la mayanización de Honduras: 1890-1940," Yaxkin 17 (1998): 85-101.

${ }^{10}$ Norman E. Whitten Jr., "El Mestizaje," Encyclopedia of Race and Racism, 2nd ed. (Detroit: Macmillan Reference, 2013), 99-104.
} 


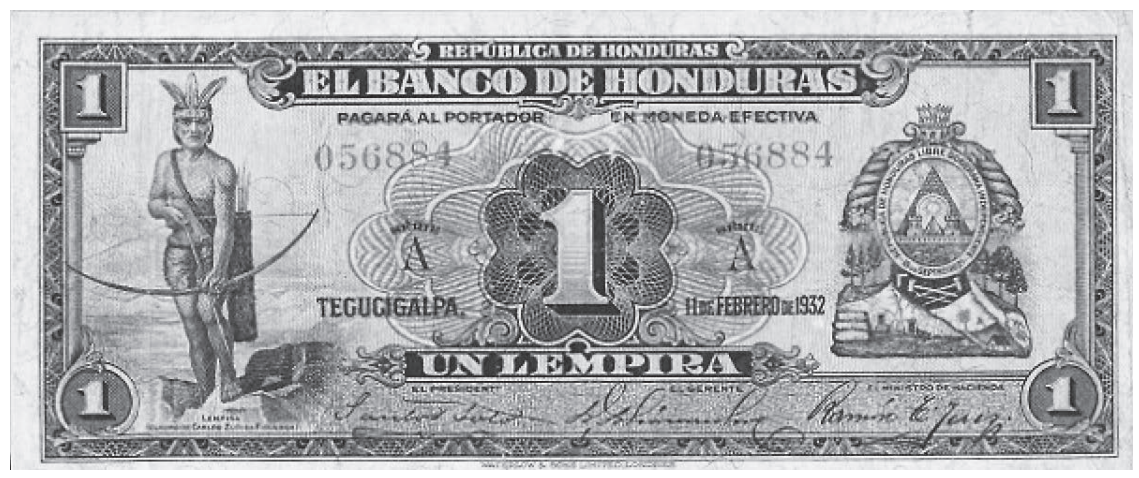

Figure 6. One Lempira banknote, 1932. Photograph by John S. Henderson.

emphasizes anti-African political sentiment: increasing reliance on black workmen by the United Fruit Company, a significant employer, triggered hostility in pro-labor factions in Honduran politics to immigration of people of African descent in general. The intensified celebration of Lempira was inevitably interpreted as a rejection, at least implicitly, of the significance of blacks and Afro-Indian mestizos in the national heritage. ${ }^{11}$ Ramón Romero saw the intense United States presence, especially but not exclusively in the banana industry, as an impediment to the development of an appropriate national identity. Copán's precolumbian monuments could be understood as representing the inverse: a distinct indigenous, authentically Honduran kernel of a national identity. ${ }^{12}$

\section{Copán-Maya Resurgence}

Renewed archaeological investigations by foreign institutions and archaeologists, beginning in the 1930s, tipped the balance again. Largely on the strength of the appeal of the monumentality of Copán's architecture and sculpture, and due to the academic and financial interests they sparked in the United States,

11 Darío A. Euraque, "La creación de la moneda nacional y el enclave bananero en la costa caribeña de Honduras: ¿en busca de una identidad étnico-racial?” Yaxkin 14, no. 1-2 (1996): 138-150; Erin Amason Montero, "The Construction of Blackness in Honduran Cultural Production" (Doctoral Dissertation, University of New Mexico, 2010).

12 Ramón Romero, Identidad nacional en Honduras: una reflexión filosófica (Tegucigalpa: Editorial Universitaria, 1990); Amason Montero, "The Construction of Blackness," 12-13. 


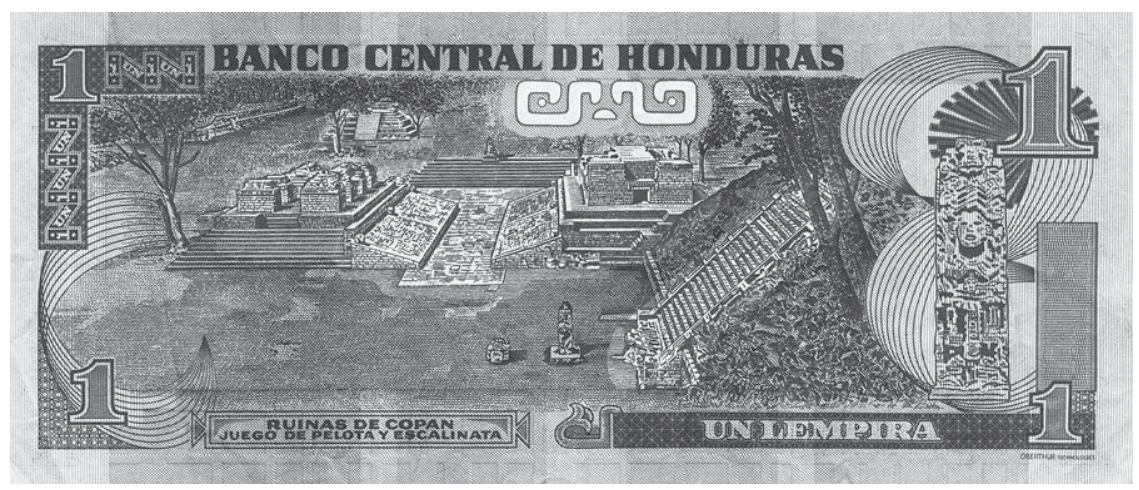

Figure 7. One Lempira banknote, 1981, reverse. Photograph by John S. Henderson.

Lempira was subsumed by the Maya component of the Honduran precolumbian heritage. A hybrid national identity crystallized in which an indigenous cultural dimension, transformed by mestizaje, was grafted onto a core defined by Copán's monumental embodiment of the Maya. The centrality of the Maya to national identity is reflected in the monuments revealed by renewed archaeological research at Copán and by the images of Copán's ancient buildings and sculptures added to the design of the one Lempira banknote so that Maya monuments frame the Lenca hero (Fig. 7). Like this new composite composition, the national identity itself is a hybrid blending monumental ancient Maya elements and indigenous components transformed by mestizaje.

The Carnegie Institution of Washington undertook a second long-term investigation of Copán ${ }^{13}$ as part of its program to explore ancient cities representing every part of the Maya world and every time period. This connected Copán and the uses to which Hondurans put it with burgeoning investigations

13 Stephen D. Houston and William R. Fowler, eds., "Remembering Carnegie Archaeology," Ancient Mesoamerica 1, no. 2 (1990): 245-276, doi: 10.1017/S0956536100000262. John M. Longyear, Copán Ceramics: A Study of Southeastern Maya Pottery (Washington, DC: Carnegie Institution of Washington, 1952; Publication 597). Gustav Stromsvik, "Substela Caches and Stela Foundations at Copan and Quirigua," Contributions to American Anthropology and History 7, no. 37 (1941): 63-96. Gustav Stromsvik, Guide Book to the Ruins of Copán (Washington, DC: Carnegie Institution of Washington, 1947; Publication 577). Gustav Stromsvik, "Ball Courts at Copán, With Notes on Courts at La Unión, Quiriguá, San Pedro Pinula and Asunción Mita," Contributions to American Anthropology and History 11, no. 55 (1952): 183-214. 
of other Maya city-states and with the developing picture of the complexities of the ancient Maya. Like the Peabody Museum project of the 1890s, the Carnegie work was firmly focused on temples, palaces, and monumental sculpture (Fig. 8); it substantially expanded the excavation and consolidation of palaces and temples. Carnegie archaeologists did not restore buildings to their original condition, but left them in "ruined" condition, framed wherever possible by trees that could be left in place without interfering with excavation (Fig. 9). The Carnegie version of the Copán Maya landscape naturalized the ancient Maya, blending their material remains with features of the natural environment. Maya city-states, their rulers, the temples, palaces and political art that sustained their power - and, by extension, the modern politicians who are their successors and the Maya national identity that helps keep them in power - were thus all made

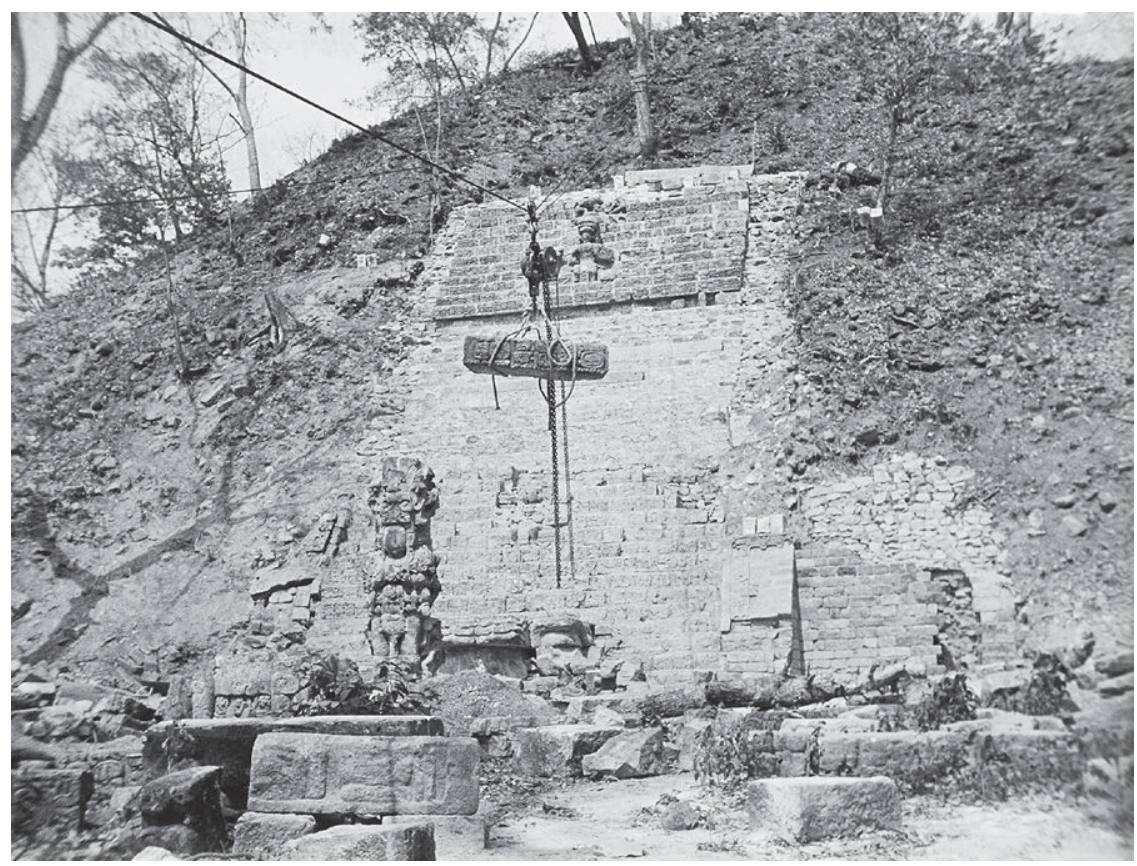

Figure 8. Copán, Structure 10L-26, Carnegie Institution of Washington repairing Hieroglyphic Stair, 1937. Photograph gift of the Carnegie Institution of Washington, 1958. (C) President and Fellows of Harvard College, Peabody Museum of Archaeology and Ethnology, Harvard University, 58-34-20/64988. 


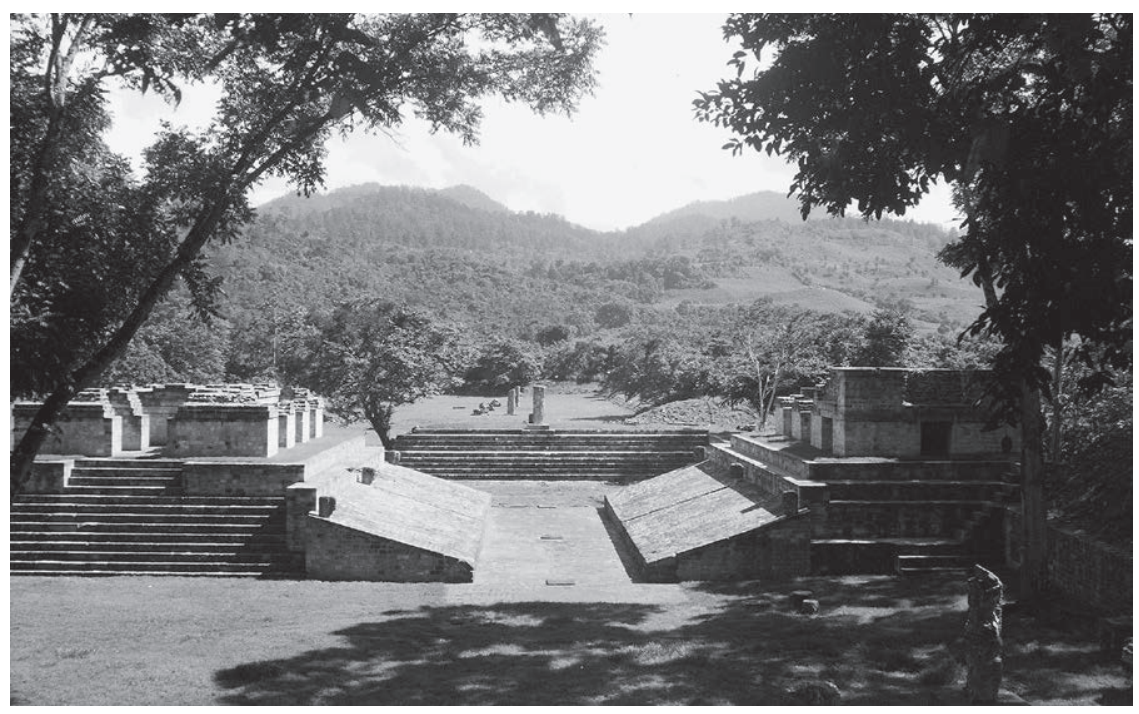

Figure 9. Copán, ballcourt, repaired by Carnegie Institution of Washington, 1941. Photograph gift of the Carnegie Institution of Washington, 1958. (c) President and Fellows of Harvard College, Peabody Museum of Archaeology and Ethnology, Harvard University, 58-34-20/38178.

part of the natural order of things. They cannot successfully be opposed. The park-like quality of Copán's archaeological landscape also transformed the exotic ancient Maya into a more manageable state for mobilization as part of the national identity project, much as mestizaje transformed exotic indigenous people.

At the same time, Parque La Concordia - located near the center of Tegucigalpa and originally built in 1883 as a memorial to president Luis Bográn was remodeled as a monument to the Maya heritage of Honduras. Its structures combine elements similar to those found on buildings and sculpture at Copán with features of Maya cities located elsewhere in Mexico and Central America. The most prominent building was inspired by the Castillo, a temple at Chichén Itzá in northern Yucatan dedicated to the feathered serpent deity known as Kukulcan, but also incorporates a figure very much like a medieval European gargoyle (Fig. 10). Casts of actual Copán sculpture serve to "legitimize" the neo-Maya compositions. A model in the style of early twentieth century Honduran public architecture and grand elite residences is placed adjacent to small Maya building models. This gives the republican Honduran elite a literal place 
in the archaeological landscape and suggests that their power is rooted in their continuation of an ancient hierarchical tradition. A small pond beneath the mature trees that shade the park situates Maya and neo-Maya elements within a "natural" environment. This constructed landscape serves to connect Honduras not only with the Maya as they are materialized at Copán, but also with other recognized centers of ancient Maya florescence and to intensify the association of the ancient Maya with dominant elites. The overall effect is to naturalize the constructed landscape that represents the hybrid whole.

A few years later, Parque El Picacho was built on an imposing hilltop overlooking central Tegucigalpa. This park was designed around buildings combining elements inspired by the architecture of Copán and other Maya cities. It was inaugurated in 1946 on the occasion of the Primera Conferencia Internacional de Arqueólogos del Caribe with great intellectual and political fanfare. It was intended to demonstrate Honduras' commitment to public archaeology and is often associated with the country's attempts to be part of the global heritage

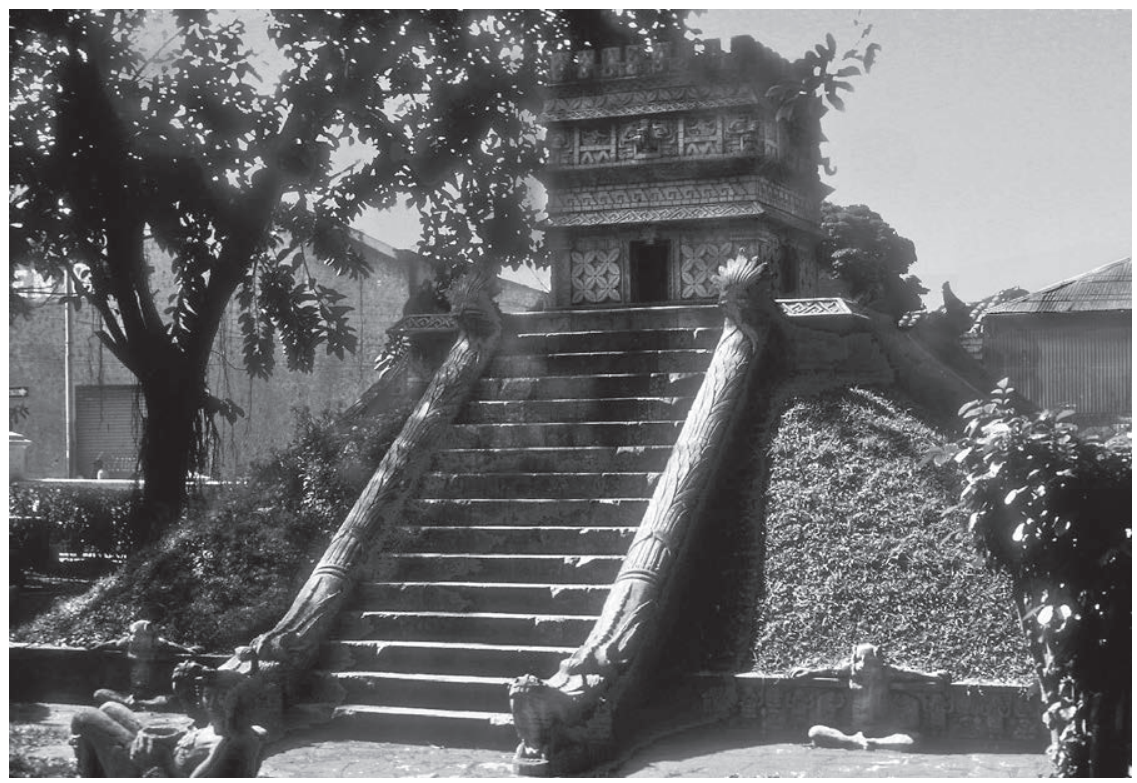

Figure 10. Tegucigalpa, Parque La Concordia, building inspired by Chichén Itzás Castillo. Photograph by John S. Henderson. 


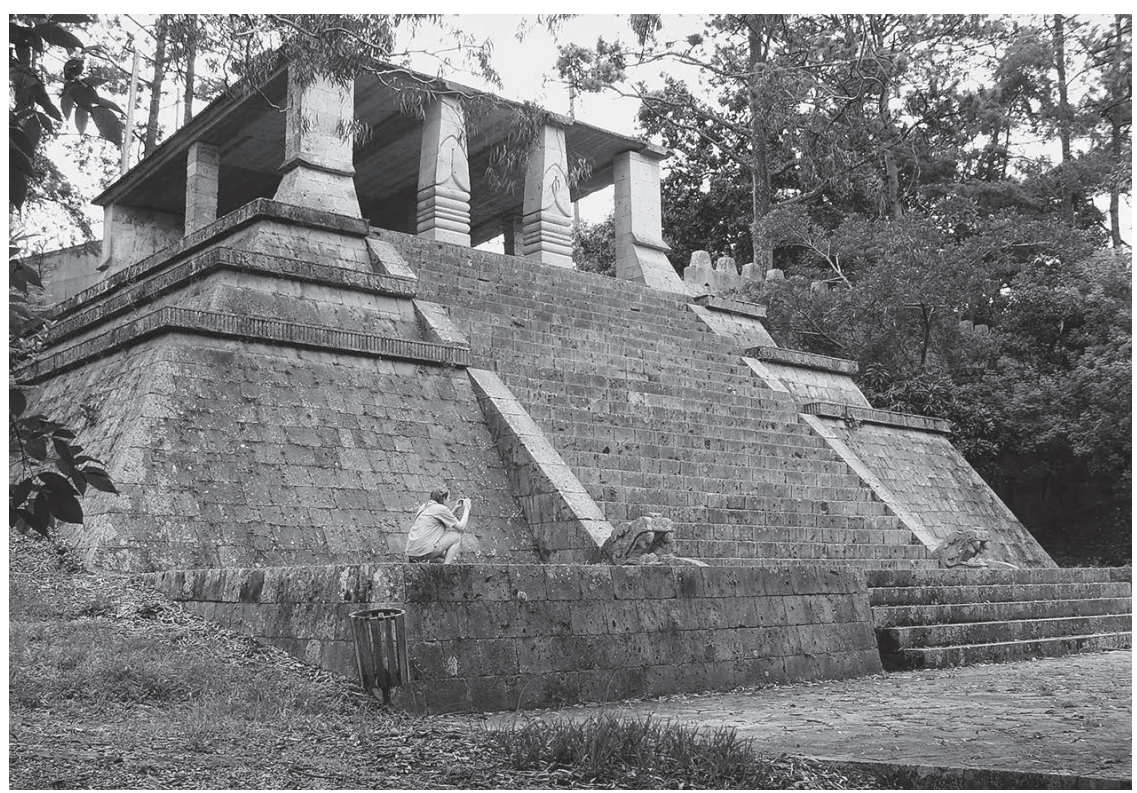

Figure 11. Tegucigalpa, Parque El Picacho, neo-Maya temple. Photograph by John S. Henderson.

movement. However, its emphasis on the Maya and focus on a re-invented Maya temple (Fig. 11) instead made manifest a national commitment to a customized and distinctly Maya past. El Picacho's neo-Maya temple is neither a replica of a particular Copán building nor a synthesis of Copán's distinctive architectural features. Instead, references to buildings at other Maya sites reflect identification with a more expansive pan-Maya international community that links Honduran history and identity with that of Mexico and other Central American nations.

The mid twentieth century also saw an uptick in archaeological exploration of Honduras beyond Copán. The Peabody Museum and the Smithsonian Institution jointly sponsored investigations in the Naco valley, the lower Ulúa valley, and the Lake Yojoa basin. ${ }^{14}$ Although Herbert J. Spinden had included the

14 William Duncan Strong, Alfred V. Kidder, and A. J. Drexel Paul, Preliminary Report on the Smithsonian Institution-Harvard University Archeological Expedition to Northwestern Honduras, 1936, Smithsonian Miscellaneous Collections 97, no. 1 (Washington, DC: Smithsonian Institution, 1938). 
lower Ulúa zone in his influential Study of Maya Art, probably on the strength of painted decorations found on the region's ceramics, ${ }^{15}$ prevailing opinion among archaeologists - mainly from the United States - working in the region was still that the absence of masonry temples and palaces and especially of stelae with hieroglyphic texts marked the region as non-Maya, without complex political organization, and consequently of much less interest than Maya city-states. Jens Yde undertook brief investigations on behalf of Tulane and the Danish National Museum in Comayagua, Yojoa, the lower Ulúa valley, the upper Chamelecón drainage and Copán. ${ }^{16}$ Doris Stone reported on more extensive excavations in the lower Ulúa valley, the Yojoa basin, the Comayagua valley and adjacent regions. ${ }^{17}$ Dorothy Popenoe directed limited excavations in the lower Ulúa and Comayagua valleys. ${ }^{18}$ Despite geographic breadth, this work was, in many cases, conditioned and framed by the persistent emphasis on Maya history in ways that aligned with North American academic interests and perpetuated a national Maya historical identity.

In the 1940s, Federico Lunardi, the papal nuncio to Honduras, published a study of Honduran ethnography arguing that all or virtually all of the indigenous peoples in the republic were Maya along with an archaeological synthesis that assigned all of the nation's material remains to ancestral Maya. ${ }^{19}$ Lunardi's vision was essentially the opposite of orthodox archaeological opinion, which identified the Maya closely with the distinctive material remains of lowland Maya city-states. It did, however, provide key elements that had been missing from the Honduran national identity project: a rationale for extending a Maya label to all of the archaeological remains in Honduras and an explicit rationale for connecting them with recent indigenous groups who could also be identified as Maya, whatever other designation might have been used for them.

15 Herbert J. Spinden, A Study of Maya Art: Its Subject Matter and Historical Development, Memoirs of the Peabody Museum of Archaeology and Ethnology 6 (Cambridge, MA: Harvard University, 1913).

${ }^{16}$ Jens Yde, An Archaeological Reconnaissance of Northern Honduras, Acta Archaeologica 9 (Copenhagen: Levin \& Munksgaard, 1938).

17 Doris Z. Stone, Archaeology of the North Coast of Honduras, Memoirs of the Peabody Museum of Archaeology and Ethnology 9 (Cambridge: Harvard University, 1941); Doris Z. Stone, The Archaeology of Central and Southern Honduras, Papers of the Peabody Museum of Archaeology and Ethnology 49, no. 3 (Cambridge: Harvard University, 1957).

18 Dorothy H. Popenoe, "Some Excavations at Playa de los Muertos, Ulua River, Honduras," Maya Research 1 (1934): 62-86; Dorothy H. Popenoe, "Ruins of Tenampua, Honduras," Annual Report. 1935 (Washington, DC: Smithsonian Institution, 1936), 559-572.

19 Federico Lunardi, Honduras maya: etnología y arqueología de Honduras (Tegucigalpa: Imprenta Calderón, 1948). 


\section{Late Twentieth, Early Twenty-First Centuries}

The constructed Maya landscape at Copán - which became the nation's first archaeological park when the Instituto Hondureño de Antropología e Historia was formed in the 1950s - has continued as a focus of national and international engagement with the invented Maya history of Honduras during the late twentieth and early twenty-first centuries. Developments in Maya archeology and shifts in theoretical perspectives in anthropological archaeology in North America contributed to new approaches to understanding Copán in the second half of the twentieth century. New work at Copán in the 1970s and 1980s focused increasingly on areas outside the civic core of the ancient city. Investigations undertaken by the Instituto Hondureño de Antropología e Historia and by the Peabody Museum focused for the first time on residential zones on the fringes

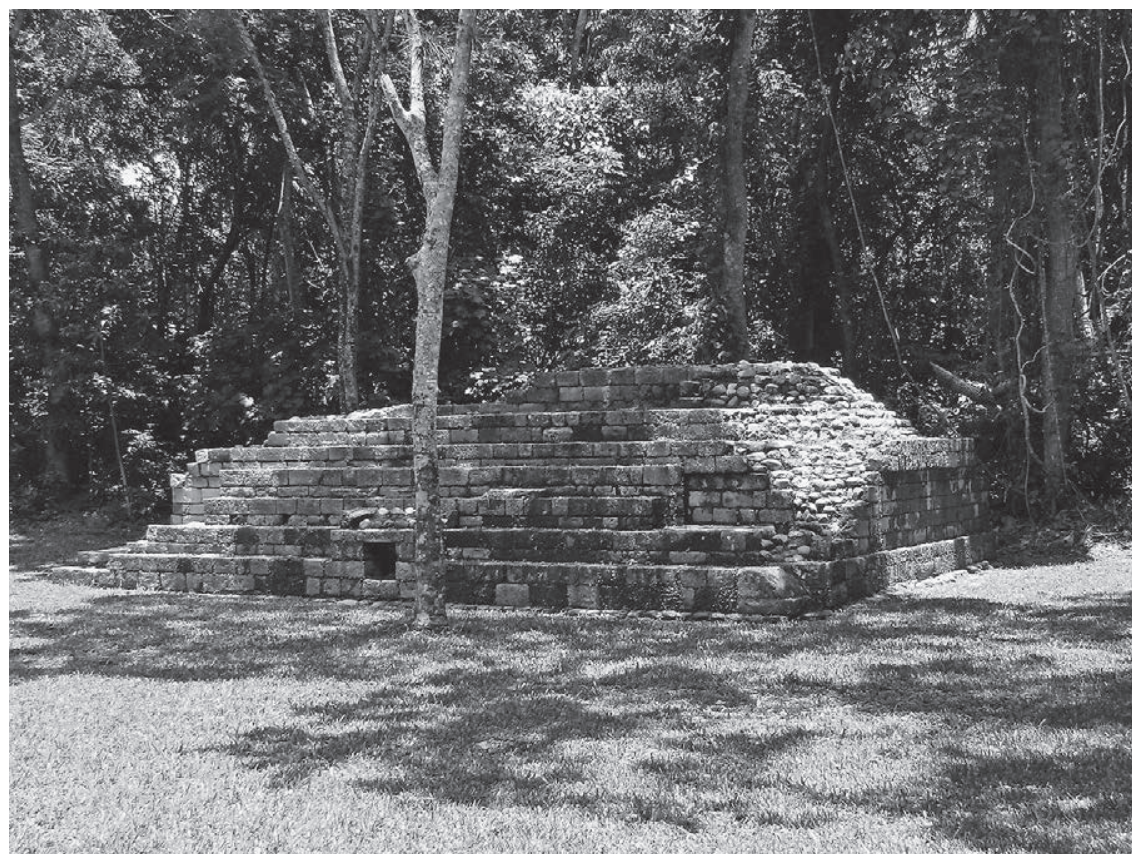

Figure 12. Copán, consolidated building in Sepulturas residential zone on the edge of the city. Photograph by John S. Henderson. 
of the city proper (Fig. 12) and on the more distant hinterland. ${ }^{20}$ The goal was to move beyond an unexamined focus on the elite and rulers to explore the distribution of material remains throughout the Copán valley as a window on the broader Copán society. The broadened perspective on the context of monumental Maya remains also included a new interest in smaller Maya centers in adjacent regions and their roles in Copán's political and economic spheres. ${ }^{21}$

Intensified interest in the archaeology of regions that lay beyond the likely reach of Copán's political and economic shadow can be understood, in part, as a reflection of this new emphasis on research designed to answer particular questions about ancient societies that had taken hold in anthropological archaeology in the United States beginning in the 1960s. A growing recognition among foreign archaeologists that they should structure their investigations to be more in line with the interests and agendas of Honduran groups and institutions has also fostered an enhanced interest in contributing to a broadened understanding of precolumbian Honduras. Work was renewed in the Naco valley, ${ }^{22}$ the lower Ulúa region, ${ }^{23}$ the Yojoa basin, ${ }^{24}$ and the Comayagua valley, ${ }^{25}$ and extended into Santa

${ }^{20}$ Claude-François Baudez, ed., Introducción a la Arqueología de Copán, Honduras, 3 vols. (Tegucigalpa: Instituto Hondureño de Antropología e Historia, 1983); Richard M. Leventhal, "Settlement Patterns at Copán, Honduras" (Doctoral Dissertation, Harvard University, 1979); William T. Sanders, ed., Excavaciones en el Área Urbana de Copán, 4 vols. (Tegucigalpa: Instituto Hondureño de Antropología e Historia, 1986-2000); David L. Webster, ed., The House of the Bacabs, Copan, Honduras, Studies in Pre-Columbian Art and Archaeology 29 (Washington, DC: Dumbarton Oaks, 1989); Gordon R. Willey, Richard M. Leventhal, Arthur A. Demarest, and William L. Fash, Ceramics and Artifacts from Excavations in the Copan Residential Zone, Papers of the Peabody Museum of Archaeology and Ethnology 80 (Cambridge, MA: Harvard University, 1994).

${ }^{21}$ Seiichi Nakamura, Kazuo Aoyama, and Eiji Uratsuji, eds., Investigaciones Arqueológicas en la Región de La Entrada, 3 vols. (San Pedro Sula: Instituto Hondureño de Antropología e Historia, 1991); William A. Saturno, "In the Shadow of the Acropolis: Rio Amarillo and its Role in the Copán Polity" (Doctoral Dissertation, Harvard University, 2000).

22 John S. Henderson, Ilene S. Sterns, Anthony Wonderley, and Patricia A. Urban, "Archaeological Investigations in the Valle de Naco, Northwestern Honduras: A Preliminary Report," Journal of Field Archaeology 6 (1979): 169-192; Patricia A. Urban, "Systems of Precolumbian Settlement in the Naco Valley, Northwestern Honduras" (Doctoral Dissertation, University of Pennsylvania, 1986).

23 John S. Henderson, ed., Archaeology in Northwestern Honduras: Interim reports of the Proyecto Arqueológico Sula (Ithaca: Latin American Studies Program, 1984); John S. Henderson, "Variations on a Theme: A Frontier View of Maya Civilization," in New Theories on the Ancient Maya, ed. Elin C. Danien and Robert J. Sharer (Philadelphia: University Museum, 1992), 161-171; Rosemary A. Joyce, Cerro Palenque: Power and Identity on the Maya Periphery (Austin: University of Texas Press, 1991).

${ }^{24}$ Claude-François Baudez and Pierre Becquelin, Archéologie de Los Naranjos, Honduras (Mexico: Mission Archéologique et Ethnologique Française au Méxique, 1973).

25 Boyd Dixon, "Prehistoric Settlement Patterns on a Cultural Corridor: The Comayagua Valley, Honduras" (Doctoral Dissertation, University of Connecticut, 1989). 
Bárbara $^{26}$; the Cajón area, ${ }^{27}$ Yoro, ${ }^{28}$ the Bay Islands ${ }^{29}$ and eastern and southern Honduras. ${ }^{30}$ Simultaneously, students of Maya hieroglyphic writing were building on the insights of Yuri Knorozov ${ }^{31}$ and Tatiana Proskouriakoff. ${ }^{32}$ By the 1970s they were beginning to produce what would become a cascade of breakthroughs in the understanding of hieroglyphic texts that we now recognized to be records of dynastic history. ${ }^{33}$ Decipherments offered biographies of named rulers, with details of their genealogies and their political and military achievements. ${ }^{34}$ The appeal of these historical specifics, which are illustrated by portraits of the protagonists on the stelae and other sculptural monuments, has proven irresistible and helped return the focus of Maya archaeology to the architectural and sculptural monuments of city centers.

The designation of Copán as a UNESCO World Heritage site in 1980 added substantially to internal and external perceptions of the status conferred by a Maya-based identity and to the economic rewards that accompanied the celebration of the site as the crown jewel of the national cultural-historical heritage. This development also reinforced the emphasis on monumental remains in Copán’s

${ }^{26}$ Wendy Ashmore, Edward M. Schortman, Patricia A. Urban, Julie C. Benyo, John M. Weeks, and Sylvia M. Smith, "Ancient Society in Santa Barbara, Honduras," National Geographic Research 3 (1987): 232-254; Edward M. Schortman, Patricia A. Urban, Wendy Ashmore, and Julie Benyo, "Interregional Interaction in the Southeast Maya Periphery: the Santa Barbara Archaeological Project 1983-1984 Seasons," Journal of Field Archaeology 13, no. 3 (1986): 259-272, 10.1179 /jfa.1986.13.3.259.

27 Kenneth G. Hirth, Gloria Lara Pinto, and George Hasemann, eds., Archaeological Research in the El Cajon Region, vol. 1 (Pittsburgh: University of Pittsburgh, Department of Anthropology, 1989).

${ }^{28}$ Christopher David Fung, "Domestic Labor, Gender and Social Power: Household Archaeology in Terminal Classic Yoro, Honduras" (Doctoral Dissertation, Harvard University, 1996); Julia A. Hendon, Houses in a Landscape: Memory and Everyday Life in Mesoamerica (Durham: Duke University Press, 2010).

29 Jeremiah F. Epstein and Vito Véliz, "Reconocimiento arqueológico de la Isla de Roatán, Honduras," Yaxkin 2, no. 1 (1977): 28-39; Vito Véliz, Gordon R. Willey, and Paul F. Healey, "Clasificación descriptiva preliminar de la cerámica de Roatán," Yaxkin 2, no. 1 (1977): 7-18.

30 Paul F. Healy, "The Cuyamel Caves: Preclassic Sites in Northeast Honduras," American Antiquity 39 (1974): 433-437; Paul F. Healy, "Excavations at Rio Claro (H-CN-12), Northeast Honduras: Preliminary Report," Journal of Field Archaeology 5 (1978): 15-28; Paul F. Healy, "Excavations at Selin Farm (H-CN-5), Colon, Northeast Honduras," Vinculos 4 (1978): 57-79; Christopher T. Begley, "Elite Power Strategies and External Connections in Ancient Eastern Honduras" (Doctoral Dissertation, University of Chicago, 1999).

${ }^{31}$ Yuri V. Knorozov, Selected Chapters from the Writing of the Maya Indians, trans. Sophie Coe (Cambridge: Peabody Museum, Harvard University, 1967).

32 Tatiana Proskouriakoff, "Historical Implications of a Pattern of Dates at Piedras Negras, Guatemala," American Antiquity 25, no. 4 (1960): 454-475, doi: 10.2307/276633.

${ }_{33}$ Michael D. Coe, Breaking the Maya Code, rev. ed. (New York: Thames and Hudson, 1999).

${ }^{34}$ Simon Martin and Nikolai Grube, Chronicle of the Maya Kings and Queens: Deciphering the Dynasties of the Ancient Maya, 2nd ed. (New York: Thames and Hudson, 2008). 
civic core, ${ }^{35}$ as has a museum built within the archaeological park during the $1990 \mathrm{~s} .{ }^{36}$ Sculptures were moved to the museum and replaced in their original settings on the site itself by replicas; fallen blocks and pieces of sculptural decoration were assembled in the museum to recreate building façades that could not be restored in their original locations without violating contemporary sensibilities and internationally recognized conventions of architectural heritage. The new museum complements the original museum built in the adjacent pueblo by the Carnegie archaeologists, which now displays mainly pottery, stone tools, jewelry and other portable objects. Utilization of Copán's Maya landscape as the backdrop for inauguration ceremonies for a recent Honduran president serves as a vivid reminder of the political functions - ancient and modern - of its palaces and temples, royal portraits and celebratory hieroglyphic texts as the apparatus of the state and its rulers and as indicators of their historical legitimacy.

Despite this resurgent Maya focus, interest in the rest of Honduras has continued among local citizens as well as foreign and domestic archaeologists into the twenty-first century. ${ }^{37}$ The Museo de Antropología e Historia de San Pedro Sula opened in 1996 to intense public interest. It is devoted to the precolumbian archaeology of the lower Ulúa valley in which San Pedro is located, which was occupied by societies that were organized quite differently from Copán. Local commitment to a focus on the region's precolumbian heritage was strong enough to stimulate resistance to government attempts to appropriate display space to feature casts of Copán sculpture.

Though discoveries outside the Copán region have included large and impressive buildings and monumental sculpture, ${ }^{38}$ archaeological remains from other parts of the country have never posed a threat to the position of Copán as

35 E.g., William L. Fash and Ricardo Agurcia, eds., Visión del Pasado Maya: Proyecto Arqueológico Acrópolis de Copán (San Pedro Sula: Asociación Copán, 1996); Robert J. Sharer, Loa P. Traxler, David W. Sedat, Ellen E. Bell, Marcello A. Canuto, and Christopher Powell, "Early Classic Architecture beneath the Copan Acropolis: A Research Update," Ancient Mesoamerica 10, no. 1 (1999): 3-23, doi: 10.1017/S0956536199101056; E. Wyllys Andrews V and Barbara W. Fash, "Continuity and Change in a Royal Maya Residential Complex at Copan," Ancient Mesoamerica 3, no. 1 (1992): 63-88, doi: 10.1017/S0956536100002315.

${ }^{36}$ Barbara W. Fash, The Copan Sculpture Museum: Ancient Maya Artistry in Stucco and Stone (Cambridge: Peabody Museum Press and David Rockefeller Center for Latin American Studies, 2011).

37 See, for example, John S. Henderson and Marilyn P. Beaudry-Corbett, eds., Pottery of Prehistoric Honduras: Regional Classification and Analysis (Los Angeles: UCLA, 1993); Eva Martínez, ed., Arqueología y Comunidades en Honduras (Tegucigalpa: Instituto Hondureño de Antropología e Historia, 2012).

${ }^{38}$ E.g., Rosemary A. Joyce and John S. Henderson, "La arqueología del periodo Formativo en Honduras: nuevos datos sobre el 'estilo olmeca' en la zona maya," Mayab 15 (2002): 5-17. 
the centerpiece of archaeology in Honduras, the focus of the Instituto Hondureño de Antropología e Historia's agendas, and the core of the national identity project. Publicity surrounding recent reports on archaeological discoveries in the Mosquitia region of northeastern Honduras ${ }^{39}$ reflects part of the reason. Sensationalized press accounts describe a "lost city" of a mysterious, vanished culture. The "lost civilization" is constructed with reference to the Maya of far western Honduras - it is represented as astounding because its material remains are substantial yet unlike those of Copán. The civilization is unknown, not because there are no archaeological remains, but because they have no familiar label. They are less complex and less monumental than those of Copán and they are clearly not Maya in style. One might have expected that the material remains would be considered a reflection of a new dimension of Honduran identity, at least of its precolumbian component. Instead they are a curiosity, less important than Maya remains, and irrelevant to Honduran national identity except insofar as they are compared to its Maya core.

The emphasis on Maya archaeological remains in relation to national identity and the insistence on Maya-ness transformed by mestizaje as the only relevant kind of indigeneity empowers Ch'orti' descendants of the Maya who built Copán and who still live in the surrounding region but has disastrous consequences for non-Maya indigenous groups. Ch'orti' entrepreneurs find it relatively easy to profit from Maya-related tourism through the sale of craft items, providing exotic cultural experiences to complement site visits, and the like. They feel secure enough as representatives of a state-favored identity group to seek a voice in the development of policy for the archaeological park and roles in its administration. They have even applied direct pressure to the national government by occupying the park for brief periods in 1998 and 2000.40

Other indigenous people have found their attempts to maintain and revitalize their cultural traditions seriously compromised by insistence on the unique relevance of the Maya to Honduran national identity and their pursuit of economic improvement through tourism hampered by the Honduran government and by the international Ruta Maya structure. Lenca people in the Copán region in particular have felt co-opted by the Maya agenda and even pressured to project

39 Douglas Preston, "Lost City Discovered in the Honduran Rain Forest," National Geographic, March 2, 2015, https://www.nationalgeographic.com/news/2015/03/150302-honduras-lost-citymonkey-god-maya-ancient-archaeology/.

${ }^{40}$ Brent Metz, "Questions of Indigeneity and the (Re)-emergent Ch'orti' Maya of Honduras," Journal of Latin American and Caribbean Anthropology 15, no. 2 (2010): 299, doi: 10.1111/j.19354940.2010.01087.x. 


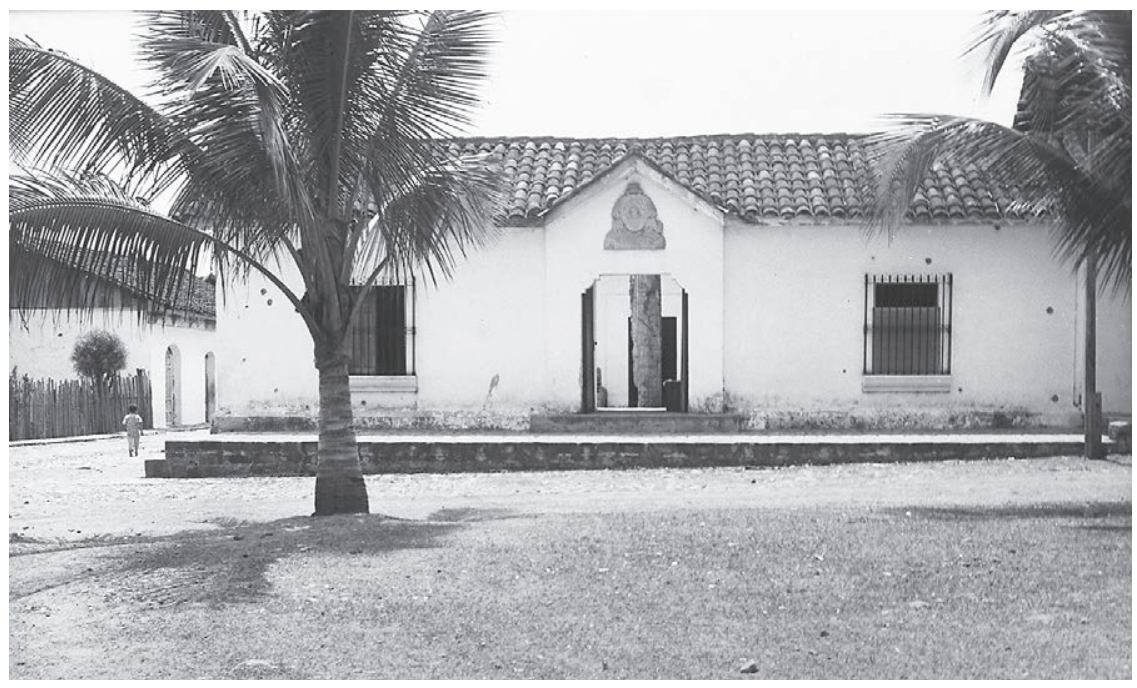

Figure 13. Copán Ruinas, museum built by Carnegie Institution of Washington with national seal of Honduras above door, 1946. Photograph gift of the Carnegie Institution of Washington, 1958. (C) President and Fellows of Harvard College, Peabody Museum of Archaeology and Ethnology, Harvard University, 58-34-20/45576.

fictive hybrid Maya-Lenca identities in order to be recognized. Copán Ruinas, the pueblo adjacent to the archaeological park, has always defined itself in relation to the ruins. For decades, the only museum in the area was the one built by the Carnegie Institution on one side of the Parque Central. The Honduran national seal over the entrance, hand-carved by Carnegie archaeologists, broadcasts the link between Copán and its Maya landscape and the Honduran state and its Maya identity while simultaneously linking both to the legitimation that comes from association with foreign archaeologists and institutions (Fig. 13). The pueblo's Parque Central was recently remodeled to feature exuberant neo-Maya style architectural and sculptural features (Fig. 14) as well as plaques honoring archaeologists involved in revealing Copán's monuments. A hieroglyphic text placed near the center of the plaza floor features the hieroglyph for Xukpi - the ancient name of Copán - surrounded by the signs for the cardinal directions. Hotels and businesses incorporate Maya elements into their premises, particularly the Xukpi name and the names of ancient Copán kings (Fig. 15). These practices certainly reflect marketing strategies, but they are also the products 


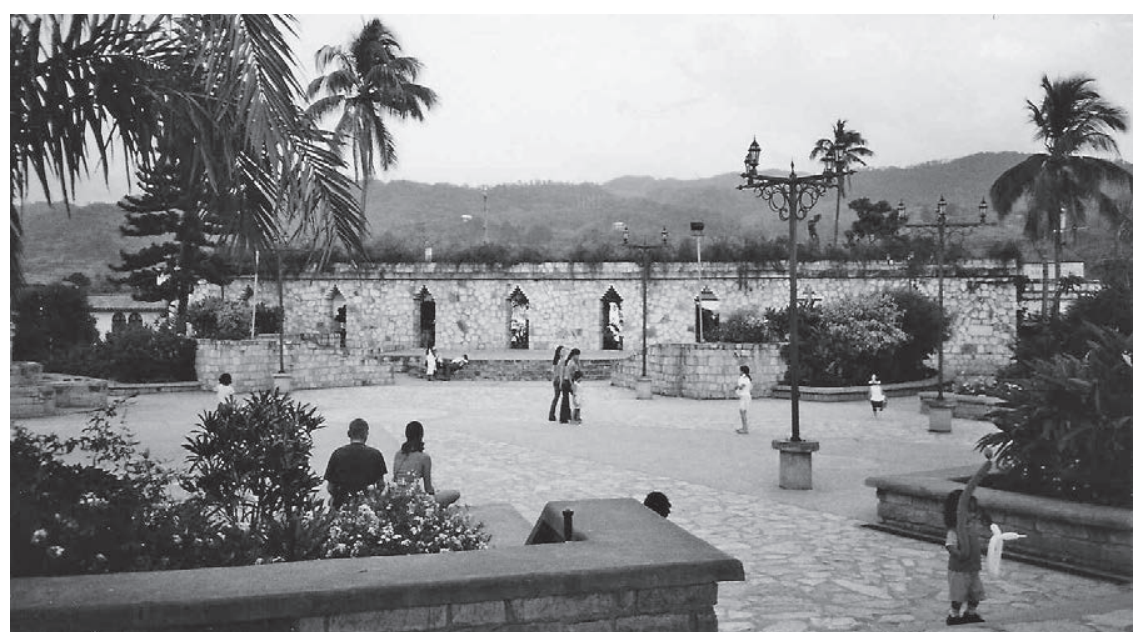

Figure 14. Copán Ruinas, parque central. Photograph by John S. Henderson.

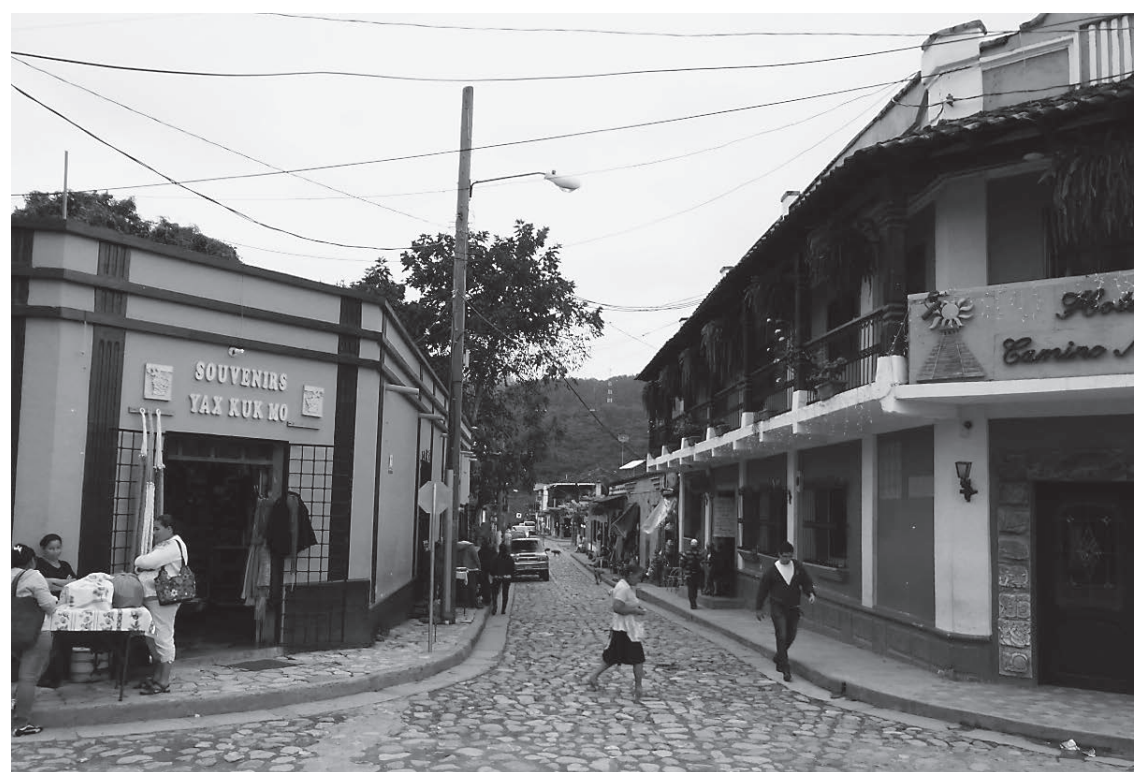

Figure 15. Copán Ruinas, street scene, souvenir shop named for Yax K'uk' Mo', the founder of the ruling dynasty of ancient Copán. Photograph by Kathryn M. Hudson. 
of intense mobilization of elements central to official national history and to the constructed landscapes that embody it. In short, they reinforce the notion of a Maya national identity connected with international prestige and prosperity.

\section{Discussion}

Honduras emerged from the Colonial period without a distinctive national identity. Precolumbian Maya civilization, which had become a focus of international attention by the mid-nineteenth century, filled the resulting identity vacuum. The government drew legitimizing power from a connection to impressive archaeological remains within the national territory and to an increasingly widely acknowledged historical narrative. Until the mid-twentieth century, locating, identifying, clearing, consolidating, documenting, and analyzing the material remains of ancient Maya city-states that formed the basis for the Honduras Maya identity project was almost exclusively undertaken by archaeologists and institutions based in the United States. In the late twentieth and early twenty-first centuries, Honduran archaeologists have had much more active roles. Most of them, however, were trained in the United States, and North American archaeologists have continued to set research agendas. From the beginning, Hondurans provided the labor that made the investigations possible.

The state project to build national identity on a Maya framework is most explicitly on display in the Museo para la Identidad Nacional in Tegucigalpa. A substantial fraction of the permanent exhibition space devoted to Honduran history is given over to precolumbian sculpture, jewelry, and other luxury artifacts, most of them reflecting Maya elite culture and rulers at Copán. A small theater screens a 25-minute film on Copán, which features monumental architecture and sculpture and recounts the history of the city's kings. The archaeology of the great bulk of Honduran national territory - which has not been occupied by the Maya in ancient or modern times - is unrepresented. Public construction projects, governmental and civil institutions, and civic events - modern and ancient - reflect cultural identifications designed to define a national character and to connect it with a broader pan-Maya heritage. The failure to acknowledge significant cultural variation in the population of Honduras after the Colonial period was actually a key element that facilitated the creation of a national identity built on a Maya heritage. The eventual recognition of the survival of indigenous people was cast in terms of transformation of indigenous identities through the process of mestizaje and focused on a generalized (fictive) Maya-ness. 
Ironically, given the high status accorded the North American archaeologists who produced the raw materials that form the foundation for Honduran Maya identity and given the centrality of monumental architecture and sculpture in that archaeological record, the characterization of material remains throughout the national territory as Maya squarely contradicts archaeological orthodoxy. Foreign archaeologists working in Honduras have almost uniformly not recognized a precolumbian Maya presence beyond the Copán region because of the absence of these material reflections of states and their institutions. Despite this, the extension of a Maya label to remains in the rest of the country has generally been left unchallenged: for Honduran archaeologists not working at Copán or in its hinterland, association with the Maya offers professional advantages, and foreign archaeologists tend to be hesitant to adopt positions that might endanger the government permits on which their work depends.

The engagement of North American antiquarians and archaeologists with the precolumbian monuments of Copán has been driven in large part by the appeal - romantic as well as intellectual - of the ancient Maya. In addition, association with the impressive Maya past offers benefits for the careers of archaeologists and for the reputations of the institutions with which they are affiliated. But, especially in the nineteenth century, an inclination to appropriate the monuments of the Maya to provide a grand historical heritage and the foundation for a national identity for the United States was also a significant part of the equation. ${ }^{41}$ The potential mobilization of the ancient Maya to create a monumental past for North America offers an interesting counterpoint to the Honduran national identity project.

As in Honduras, controversy about the relationship of indigenous people to archaeological remains complicated thinking about the pre-European history of the United States. ${ }^{42}$ For much of the nineteenth century there was a consensus that construction of substantial ancient mounds, particularly prominent in the Mississippi and Ohio valleys, was beyond the capabilities of American Indians and that they should be attributed to a vanished race of "Moundbuilders." This entirely fictitious group was most often supposed to have migrated to North America from the Mediterranean and Near East, bringing with them their more "advanced" culture. Joseph Smith, founder of the Church of Jesus Christ of Latter-day Saints offered a compromise perspective: American Indians themselves

\footnotetext{
${ }^{41}$ Thomas C. Patterson, A Social History of Anthropology in the United States, 2nd ed. (New York: Routledge, 2021), 4.

42 Ibid., 18-25.
} 
were the descendants of migrants from the ancient Mediterranean. ${ }^{43}$ Whatever the ultimate origins of the Moundbuilders, the key consideration in relation to a pre-European historical foundation for the United States was their relationships to ancient monuments. As early as 1820, the American Antiquarian Society articulated the critical perspective:

We see a line of ancient works, reaching from the south side of Lake Ontario to the banks of the Mississippi, through the upper parts of Texas, around the Mexican Gulf, quite into Mexico: increasing in number, and improving in every respect as we have followed them; and showing the increased numbers and improved condition of their authors, as they migrated toward the country where they finally settled. ${ }^{44}$

This interpretation, fully consistent with Mormon belief, came to be widely shared by antiquarians interested in the precolumbian remains of Mexico and Central America. It provided a rationale for appropriating those monuments to create a majestic historical foundation for the United States.

Stephens accepted the interpretation of a common ancestry for the monuments of the territory stretching from New England to Central America. His goals in undertaking exploration of Maya sites and in acquiring Maya antiquities were largely pecuniary: he wanted to maximize sales of his travel books and he hoped to generate income by charging admission to exhibitions of Maya antiquities. But he also wanted to contribute to the creation of an impressive past for the young nation. He sought the position of diplomatic envoy to the República Federal de Centroamérica and he used the status it lent him in his attempts to acquire Maya monuments. As he remarked, his formal diplomatic coat with its "profusion of large eagle buttons" 45 was a great help in his quest

To buy Copán! Remove the monuments of a by-gone people from the desolate region in which they were buried, set them up in "the great commercial emporium" [New York], and found an institution to be the nucleus of a great national museum of American antiquities! ${ }^{46}$

\footnotetext{
${ }^{43}$ Joseph Smith, Jr., Book of Mormon: An Account Written by the Hand of Mormon upon Plates Taken from the Plates of Nephi and translated by Joseph Smith, Jr. (New York: E. B. Grandin, 1830).

${ }^{44}$ Archaeologica Americana: Transactions and Collections of the American Antiquarian Society (American Antiquarian Society, Worcester, MA, 1820), 245.

45 Stephens, Incidents of Travel in Central America, Chiapas, and Yucatan, vol. 1, 127-128.

46 Ibid.,115.
} 
He also attempted to purchase Quiriguá, Palenque, and Uxmal; he imagined installing the latter on the banks of the Mississippi, surrounding it with a fence, and charging admission. ${ }^{47}$ Stephens insisted explicitly that the antiquities of Mexico and Central America were rightfully part of the historical heritage of the United States and he believed that they would contribute substantially to putting it on an equal footing with much older European nations with respect to material remains of grand historical roots. ${ }^{48}$

In the second half of the nineteenth century, multiple voices echoed Stephens's desire to prevent not only European powers but also new Latin American nations from claiming precolumbian monuments as part of their heritage. Mormons, many of whom were settling in Mexico, considered the United States to be the preeminent American power and saw Mexican and Central American antiquities as reflections of the initial stage of an American civilization embodied in their day by the United States. Both Charnay and Le Plongeon subscribed to the notion of a United States historical heritage that embraced the precolumbian remains of Mexico and Central America.

As the Peabody Museum investigations proceeded at Copán, the United States claim to the antiquities of Mexico and Central America was materialized at the 1893 World Columbian Exposition. Exhibits representing precolumbian history - designed by Frederick Putnam, director of the Peabody Museum - featured full-size recreations of ancient monuments and building facades based on molds by Charnay and Edward Thompson, along with Maudslay's large-format photos. These exhibits - located to mirror the Fine Arts building that highlighted U.S. achievements in the arts - were presented as the historical prelude to the pinnacle of American development. The precolumbian exhibits were installed in the new Field Museum in Chicago and the Fine Arts building eventually became the home of the Art Institute of Chicago. ${ }^{49}$

For much of the later nineteenth century, especially in the aftermath of the "French Intervention," Mexico seemed politically unstable and appropriation of its precolumbian monuments by the United States - increasingly eager to identify material remains that could be represented as a reflection of its historical foundations and a legitimation of its influence on the international stage - seemed

${ }^{47}$ John L. Stephens, Incidents of Travel in Yucatan (New York: Harper and Brothers, 1843), vol. 1, 136.

48 Stephens, Incidents of Travel in Central America, Chiapas, and Yucatan, vol. 1, 115-116, and vol. 2, 474.

49 Evans, Romancing the Maya, 153-160; Patterson, A Social History of Anthropology in the United States, 42-43. 
plausible. By the end of the century, this trajectory was definitively on the wane. Le Plongeon had inadvertently contributed to strengthening Mexico's grip on its precolumbian heritage through an abortive attempt to export a particularly well-preserved chacmool sculpture from Chichén Itzá. The decisive intervention of Yucatecan officials and the president firmly established Mexico's interest in and control of its precolumbian monuments despite foreign attempts to coopt them. ${ }^{50}$ The emergence of a stable Mexico in the third decade of the twentieth century, following the revolution, signaled the definitive end of any prospect of the United States acquiring additional territory and of serious attempts to appropriate its precolumbian heritage. Maya antiquities had become objects of academic interest and embodiments of the exotic for tourists. United States archaeologists and institutions continued to shape Maya archaeology in Mexico and Central America into the twenty-first century - and to enjoy the benefits of their preeminence in that field - but a desire to represent Maya monuments as material reflections of U.S. historical roots was no longer part of the agenda.

Through the Carnegie investigations in the 1940s, archaeology at Copán focused almost exclusively on monumental architecture and sculpture. These obvious reflections of ancient Maya city-states and their ruling elites were a central component of the Maya identity project. Following the Carnegie expeditions, large-scale fieldwork did not resume at Copán until the 1970s. The foci of new projects directed by Claude Baudez and William Sanders reflected major shifts that had taken place in anthropological archaeology in the interim: a transition away from trappings of states and rulers and concomitant focus on settlement archaeology, particularly in the remains of the domestic life of non-elite components of complex societies. In the case of the Maya world this involved a new interest in the demography of the people living outside the civic cores of the great political centers, especially in their economic contribution to the maintenance of states and rulers. Even though it drew academic attention away from the monuments that had long been the focus of public discourse on Honduran history and the Maya, this shift did not dislodge Maya-ness as the key component of Honduran history and identity; by this time, Copán and its architectural and sculptural monuments were established as the precolumbian core of national history.

The same re-focusing of archaeological perspectives also fostered intensified investigations in other regions of the republic along with comparative and synthetic analyses that situated interpretation of archaeological remains throughout

${ }^{50}$ Desmond and Messenger, A Dream of Maya, 42-49; Evans, Romancing the Maya, 134-135. 
the republic in the same analytical domain. ${ }^{51}$ While not a renewal of Lunardi's notion that all Honduran archaeological remains were Maya, this change did nurture a perspective that envisioned a Honduran archaeology that was truly national, embracing Copán and the rest of the republic. For academic archaeologists, greater attention to non-elite components of precolumbian societies reflected theoretical developments that involved a new concern with variability within and across regions. In Honduras, one result was to encourage engagement in the Maya identity project by a broader spectrum of Honduran citizenry, although that was not necessarily part of a conscious strategy.

Rapid progress in the decipherment of Maya inscriptions in the 1970s and 1980s tipped the balance back toward state institutions and ruling elites that became increasingly identifiable as named individuals with partially documented biographies. The Mexican site of Palenque was the initial focus of this work, but epigraphers were soon delineating Copán's rulers and their history. By late 1980 s, the focus of archaeological excavation was also shifting in ways that reemphasized the civic core and the trappings of kings and states. This reinforced the place of monumental remains of ancient Maya state as the core of Honduran official Maya history.

In the early years of the twenty-first century, archaeological investigations were active in almost every part of the republic ${ }^{52}$ and the Instituto Hondureño de Antropología e Historia was actively promoting investigations outside the Copán region in the interest of reducing Copan's domination of national archaeology. To some degree, this expansion of geographic focus reflected new theoretical interests in archaeology, but it was stimulated in part by political rivalries within the Instituto Hondureño de Antropología e Historia. The 2009 coup in Honduras interrupted that process; arguably - as Amason Montero, following Darío Euraque, suggests - the new regime believed that maintaining the monumental Maya focus would offset perceptions that the republic had been de-stabilized. ${ }^{53}$

The failure of archaeologists to develop explicit definitions of cultural categories contributed to the mismatch of academic and popular understandings of "Maya." Since the end of the nineteenth century, archaeologists working in the lowlands of northern Guatemala, Belize, and eastern Mexico have treated monumental architecture and sculpture - especially temples, palaces, and stelae with portraits of rulers and hieroglyphic texts celebrating their genealogies,

\footnotetext{
${ }^{51}$ Henderson and Beaudry-Corbett, eds., Pottery of Prehistoric Honduras.

52 Martínez, ed., Arqueología y Comunidades en Honduras.

53 Amason Montero, "The Construction of Blackness," 8-9.
} 
their great deeds, and their connections with supernatural beings - as distinctive archaeological markers of a conceptually homogenized Maya civilization and, by extension, the precolumbian Maya in general. In fact, of course, these are features of city states; they reflect the activities and interests of ruling elites and they functioned largely to maintain and enhance their power. These features are not well suited as markers of a Maya cultural tradition: daily lives and material culture of other social groups were only indirectly related to city-state trappings. Moreover, monumental architecture and political art were absent from much of the territory occupied by speakers of Mayan languages, assumed by most archaeologists to be coterminous with the extent of a Maya cultural tradition. ${ }^{54}$

Not surprisingly, public intellectuals and state actors who took leading roles in appropriating the precolumbian Maya for the Honduran national history and identity project never overtly recognized "Maya" as a cultural construction. Interestingly, archaeologists did not do so explicitly until well into the twenty-first century. Beginning in the late 1980s, concepts like the self, the other, subjectivity, and cultural construction came to be common in anthropological analysis, stimulated by the work of Foucault and other postmodernists. ${ }^{55}$ Despite that shift and the simultaneous ferment in social anthropology and history about Maya and other ethnicities, especially in highland Guatemala and Chiapas, academic archaeologists continued to treat "Maya" as an unproblematic label for an objectively defined category. ${ }^{56}$

The failure of Lempira to maintain a central place in the official version of Honduran history and identity in the face of growing emphasis on a precolumbian Maya past can be attributed, in large part, to the absence of impressive material remains associated with him and with the Lenca in general. In the same way, the inability of the United States to possess or control the majestic architecture and political art of ancient Maya city-states made it impossible to appropriate the Maya in service of the creation of a national identity. Information on ancient societies - even by the most authoritative academic voices and institutions - are insufficient to constitute the foundation for national history and identity; actual monuments are essential.

${ }^{54}$ John S. Henderson and Kathryn M. Hudson, "The Myth of Maya: Archaeology and the Construction of Mesoamerican Histories," in On Methods: How We Know What We Think We Know About the Maya, ed. Harri Kettunen and Christophe Helmke (Markt Schwaben: Anton Saurwein, 2015), 7-24.

55 Patterson, A Social History of Anthropology in the United States, 158-159.

56 See Kay B. Warren, "Introduction: Rethinking Bi-Polar Constructions of Ethnicity," Journal of Latin American Anthropology 6, no. 2 (2001): 90-105, doi: 10.1525/jlca.2001.6.2.90 for a perceptive overview of early discourse on these issues. 
In Honduras, emphasis on the monumental dimension of the material remains of the precolumbian Maya and the Maya component of the recent indigenous population reified a single strand of the country's complex and multi-faceted past as the essence of its history. Honduras gained a national identity rooted in its distinctive past, and the republic made itself part of a historical narrative that continues to attract substantial international attention. The consequences of these processes are not, however, positive for all elements of Honduran society. The corollary of this asserted national Maya identity is marginalization of other indigenous cultural traditions. Lempira, a non-Maya folk hero revered as a leader of resistance against the Spanish invasion, provides the most obvious illustration: he is depicted on the currency named after him framed by memorializing objects and monumental buildings from the ancient Maya city of Copán. In this and other ways, the official emphasis on Maya heritage in the development of a national Maya identity not only ignores the complexities and contingencies of identity, ancient and modern - especially in relation to the state - but also erases the diversity of the Honduran people and their cultural achievements in the past and in the present. Even the living Maya are marginalized and are not among those who benefit most from the tourist industry based on the creations of their ancestors. ${ }^{57}$

The emphasis on the material remains that ancient Maya states used to legitimize power naturalizes the social stratification and inequalities that characterized them, thereby rationalizing the same conditions in the modern republic. The creation of an archaeological park at Copán contributed to the same process, encompassing the essence of precolumbian Maya civilization within a framework that made explicit the dominance of the state and the national history and identity it espoused. The precolumbian Maya were effectively part of a process of mestizaje. Honduran Maya history is thus memory politics writ large and an illustrative manifestation of how monumental remains of complex and troubled pasts, interpreted for public consumption in simplified ways not necessarily congruent with orthodox archaeological opinion, can shape the future.

57 Warren, "Introduction"; Jean E. Jackson and Kay B. Warren, "Indigenous Movements in Latin America, 1992-2004: Controversies, Ironies, New Directions," Annual Review of Anthropology 34 (2005): 549-573, doi: 10.1146/annurev.anthro.34.081804.120529; Carleen D. Sánchez, "Creando la identidad nacional entre las ruinas," in Estudios culturales centroamericanos en el nuevo milenio, ed. Gabriela Baeza Ventura and Marc Zimmerman (San José: Editorial Universidad de Costa Rica, 2009), 94-103. 